\title{
Some Haematological Data on Pregnant Gurkha Women
}

\author{
Capt T O Jefferson
}

$M D, D R C O G$, RAMC

\author{
Capt A J Reidy
}

BM BS, BMedSci, DRCOG, RAMC

\section{Capt P M D Kennedy}

MB BS, BSc, DRCOG, RAMC

New Territories Group Practice, Borneo Lines

SUMMARY: In a retrospective survey of 285 pregnancies in Gurkha women living in the New Territories of Hong Kong, the mean values of Haemoglobin, Mean Cell Volume and Mean Cell Haemoglobin Concentration were examined with the aim of establishing basic data.

\section{Introduction}

The female Gurkha population of the New Territories of Hong Kong is cared for antenatally, postnatally, and sometimes intranatally, at Gurkha Family Hospitals situated in the Family Lines in the various Gurkha Units.

Ethnically they are a homogeneous population, belonging, for the majority, to the middle strata of the Nepali Hindu caste system. Whereas in their native Nepal their food intake is quantitatively and qualitatively restricted by poverty, once in Hong Kong their diet is enriched, making the effects of previous malnutrition difficult to assess clinically and haematologically.

Previous detailed published data on pregnant Gurkha women of Nepali stock whose husbands have joined the British Army is scarce. This makes it imperative to lay down some basic data against which improvements can be judged in years to come.

\section{Methods}

Blood was taken from 285 consecutive women at their first antenatal visit, who all attended within the first 16 weeks of pregnancy. The length of gestation was established either by computing the length of amenorrhoea, or, when the exact date of the last menstrual period was not known, by estimation of the fetal bi-parietal diameter by ultrasound scan.

Venous blood was collected in a haematology Sequestrene bottle and the Haemoglobin (Hb), Mean Cell Value (MCV) and Mean Corpuscular Haemoglobin Concentration (MCHC) were obtained by an automatic blood counter (Coulter). None of the patients had received iron or folate supplements before their first attendance at the antenatal clinic.

\section{Results}

The overall results with the Standard Deviatiote (SD) for each value are shown in Table I. Table $\mathrm{B}$ shows the Mean Haemoglobin (Hb), Mean Cef Value (MCV) and Mean Corpuscular Haemoglob Concentration (MCHC) with Standard Deviatio (SD) for Gurkha Women of different gravidity, $\vec{\bullet}$ name ly primigravidae, gravida $2-4$ inclusive ang gravida 5 and above.

Table I

Overall (Mean) 285 Pregnancies

\begin{tabular}{rrlrlr}
\hline $\mathrm{Hb}$ & 12.42 & $\mathrm{MCV}$ & 85.34 & $\mathrm{MCHC}$ & 34.38 \\
$\mathrm{SD}$ & 1.27 & $\mathrm{SD}$ & 7.44 & $\mathrm{SD}$ & 1.01 \\
\hline
\end{tabular}

Abbr. $\mathrm{Hb}-\mathrm{Haemoglobin}$ (expressed in gramsideciliter); MCV-Mean Cell Value (expressed in fl); MCHC - Mean Corpuscular Haemoglobin Concentration (expressed in grams/deciliter); SD-Standard Deviation.

\section{Table II}

\begin{tabular}{|c|c|c|c|c|c|}
\hline $\mathbf{r a}$ & lean, & Preg & cles & & \\
\hline $\mathrm{Hb}$ & 12.30 & MCV & 86.77 & $\mathrm{MCHC}$ & 33.89 \\
\hline SD & 1.84 & SD & 5.45 & SD & 1.03 \\
\hline
\end{tabular}

Gravida 2-4 (Mean) 181 Pregnancies

$\begin{array}{rrlrlr}\text { Hb } & 12.15 & \text { MCV } & 84.84 & \text { MCHC } & 34.64 \\ \text { SD } & 2.29 & \text { SD } & 5.51 & \text { SD } & 2.7\end{array}$

\begin{tabular}{crlrll} 
Gravida & 5 & (Mean) & Pregnancies & & \\
Hb & 12.27 & $\mathrm{MCV}$ & 83.46 & $\mathrm{MCHC}$ & 31.89 \\
$\mathrm{SD}$ & 3.6 & $\mathrm{SD}$ & 6.21 & $\mathrm{SD}$ & 4.91 \\
\hline
\end{tabular}

Abbr. As in Table I. 


\section{Discussion}

Only eight patients in our survey were found to have Haemoglobin concentration below $10.0 \mathrm{~g} / \mathrm{dl}$, and 28 others had a Haemoglobin between 11.0 and $10.0 \mathrm{~g} / \mathrm{dl}$.

The overall figures obtained by our survey compare favourably with other data obtained in pregnant women of European descent, where the Haemoglobin was found to be $13.2 \mathrm{~g} / \mathrm{dl}$ between the eighth and twelfth week of gestation ${ }^{1}$. In our sample no comment is possible on the Haematological status during the rest of the pregnancies.

It is interesting to note also a slightly higher mean Haemoglobin concentration of $1.5 \mathrm{~g} / \mathrm{dl}$ in favour of our Gurkha population compared with pregnant Malaysian aborigine women at the same length of gestation ${ }^{2}$.

There seems also to have been a marked improvement in the Haemoglobin concentrations of pregnant Gurkha women.

This is evident when one takes into consideration the results of a survey of 170 pregnant Gurkha women in Malaysia in the early 1960's. (Bernstein, Personal Communication). 18 of these women, although mostly in the third trimester of their pregnancies and even after iron and vitamin supplementation had, Haemoglobin concentrations of 9.2 $\mathrm{g} / \mathrm{dl}$ or below. Although these women were further on in their pregnancies than our population and no gravidity breakdown figures are available, the improvement in the Haematological indices seems remarkable.

Our Gurkha population has Haemoglobin levels which are not far from those of a European population. Factors such as malnutrition and helmintic infestation seem now to be of less significance than previously.

\section{Acknowledgements}

The authors are grateful to $\mathrm{Col} S$ Bernstein $\mathrm{L} / \mathrm{RAMC}$ for the help received and permission to quote the results of his survey.

\section{REFERENCES}

1 De Gruchy G C. Clinical Haematology in Medical Practice, Blackwell, London. 4th Ed. 1978: 222.

2 ONG H C. Obstetrical Data in Malaysian Aborigine Woman. Trop Georgr Med 1974; 384-388.

\section{Academic Achievements}

MRCPsych Capt H G Bosanquet, MB, ChB, RAMC Capt M E Piper, LMSSA, RAMC

\section{Honorary Consultants to the Army}

Mr. A H Chignell, FRCS, was appointed Honorary Consultant in Ophthalmology to the Army with effect from 8 November 1983. He succeeds Mr J Winstanley who retired on 8 July 1983.
Mr. A McCalister, TD, MCh, FRCS, FRCSI, was appointed Honorary Consultant in General Surgery to the Army in Northern Ireland with effect from 12 December 1983. He succeeds $\mathrm{Mr}$ E Morrison who retired on 11 October 1983. 